\title{
Malignant Pleural Mesothelioma: State of the Art
}

Editor

BRYAN M. BURT

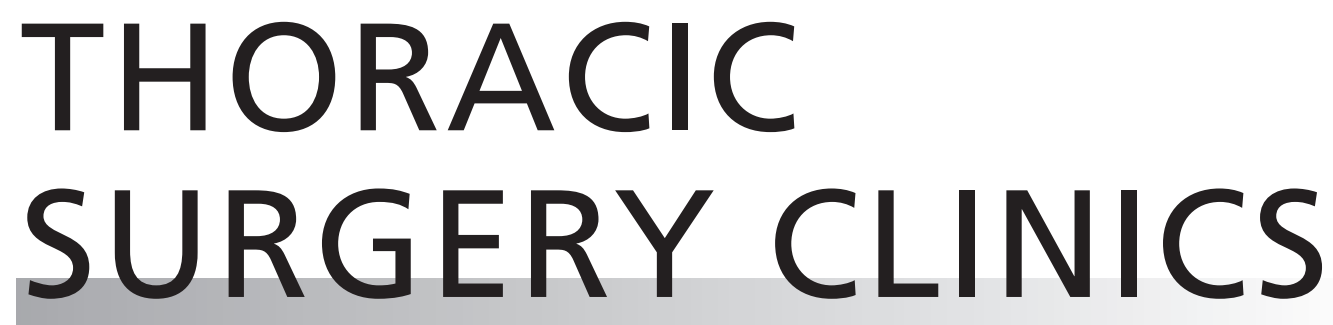

www.thoracic.theclinics.com

Consulting Editor

VIRGINIA R. LITLE

November 2020 • Volume 30 • Number 4 